\title{
A Ranking Method for User Recommendation Based on Fuzzy Preference Relations in the Nature Reserve of Dangshan Pear Germplasm Resources
}

\author{
Ali Mohsin, Qiong Shen, Xinyu Wang and Xiaoming Zhang *(i) \\ School of Information and Computers, Anhui Agricultural University, Hefei 230031, China; \\ mohsinali722@gmail.com (A.M.); shenqiong@gbl-gz.com (Q.S.); missing_youth@126.com (X.W.) \\ * Correspondence: xmzhang@ahau.edu.cn; Tel.: +86-133-6560-9291
}

Received: 12 October 2018; Accepted: 12 November 2018; Published: 19 November 2018

check for updates

\begin{abstract}
Precision orchard management is an important avenue of investigation in agricultural technology and is an urgently needed part of information development in the fruit industry. Precision management based on a precision agricultural technology system involves many factors and results in users being unable to make accurate judgments. To improve user decision-making accuracy and the level of precision management, we used user preferences to achieve the recommendation function. In this paper, a ranking method based on fuzzy preference relations for user recommendation is proposed. We selected the Nature Reserve of Dangshan Pear Germplasm Resources as the research location and invited experts and representatives of different roles (government, farmers, and tourists) to give the fuzzy preference relation coefficients. Then, an optimization model was proposed based on the fuzzy preference relation. We solved the proposed model by constructing a Lagrangian function, and obtained the ranking values of the user preference recommendation function. Finally, we ranked the order of the given roles and implemented the fuzzy preference recommendation. The experimental results show that the proposed method is effective and can be conveniently applied to other problems related to user preference relations.
\end{abstract}

Keywords: precision orchard management; decision analysis; fuzzy preference relations; alternative ranking; recommended function; Lagrangian function

\section{Introduction}

With the massive changes brought about in the information era, China has been deeply affected. A series of successive information technologies have been applied to agriculture, resulting in the development of technologies such as precision agriculture, orchard informatization, digital orchard management, and precision orchard management. Precision orchard management is not only an important part of orchard management, but also the main research direction of precision agriculture. Because China has a large fruit industry, there is a need to apply precision orchard management technology to deal with the huge production in a better way.

Precision agriculture is a modern agricultural operation technology system that comprises a set of technologies that combines sensors, information systems, enhanced machinery, and informed management to optimize production by accounting for variability and uncertainties within agricultural systems [1]. The goal of precision agriculture is to manage the inputs on site to get the maximum production [2]. At present, precision agriculture technology has been studied in China and other countries at multiple levels with multiple perspectives. Related technologies can provide a technical reference for the accurate management of orchards [3]. However, fruit trees and orchards have their own characteristics, especially in the Nature Reserve of Dangshan Pear Germplasm Resources. 
The Nature Reserve of Dangshan Pear Germplasm Resources is located in Dangshan County, Anhui Province, China. It includes 17 villages in Dangshan County. The protected features include not only more than 10 Dangshan Crisp Pear germplasm resources, more than 40,000 pear trees of over 100 years old, but also the Yellow River wetland and its ecological system. The general situation of the Nature Reserve of Dangshan Pear Germplasm Resources is shown in Figure 1. Therefore, the management of this nature reserve is different from general nature reserves which are strictly protected, and it is an open protection area for the protection of Crop Germplasm resources. There is not only the government managing the reserve, but also local farmers producing fruit trees, as well as tourists visiting the nature reserve. Therefore, different types of people have different objects of concern in protected areas. By investigating the preferences of different groups of people, the main features in the reserve are sorted according to preference, which will give different groups a better experience of the reserve.

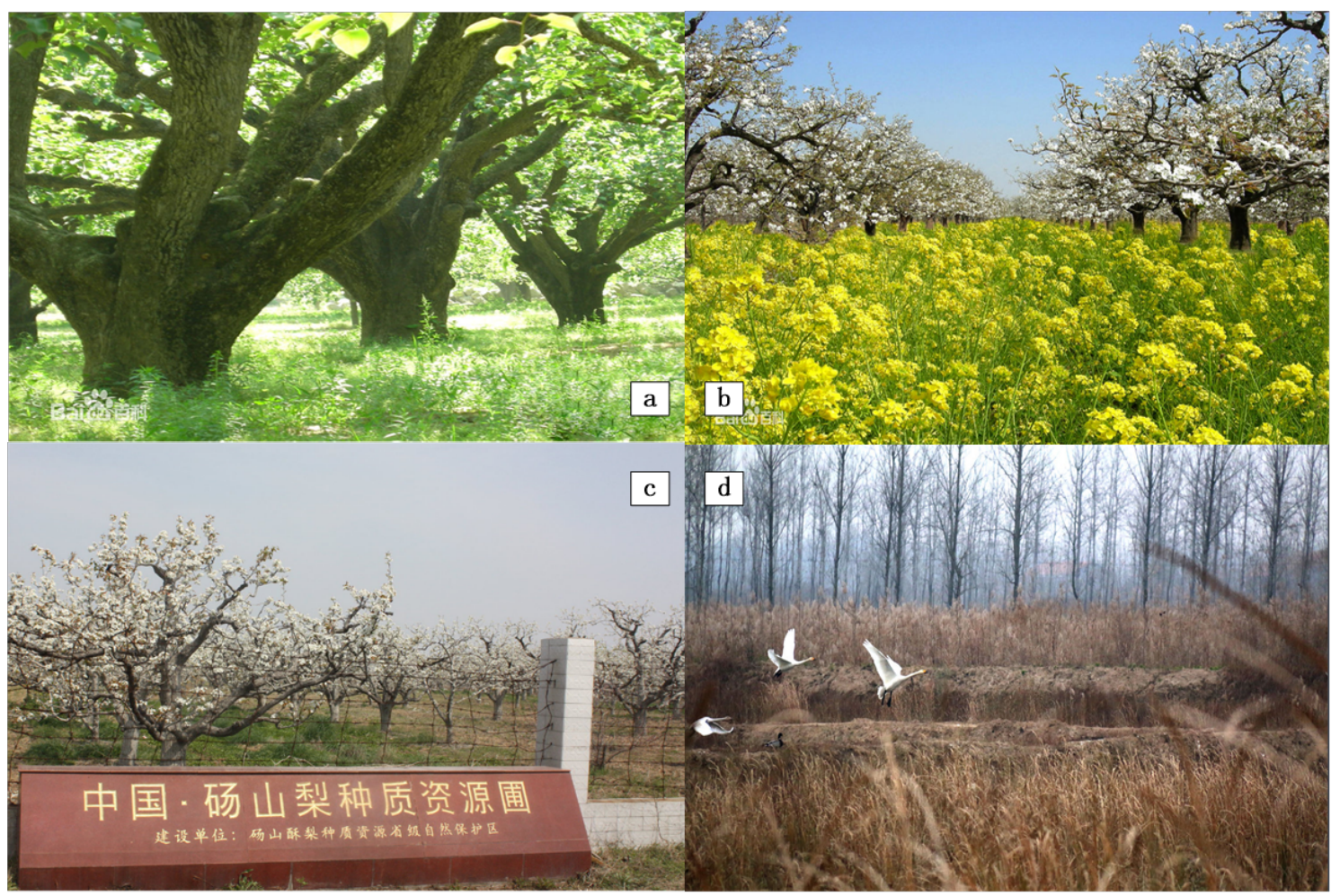

Figure 1. General situation of the Nature Reserve of Dangshan Pear Germplasm Resources. (a) Shows pear trees of over 100 years old; (b) Shows a pear orchard and farmland; (c) Shows pear germplasm resources repositories; (d) Shows the Yellow River wetland.

To improve the accuracy of user decision making and the level of precision management, we applied a ranking method for user recommendation based on fuzzy preference relations. Fuzzy set theory was proposed in 1965 by Zadeh, and many scholars have since used it to solve decision making problems [4]. These problems include supplier selection [5], investment load evaluation [6], ordinal peer assessment [7], 0-1 mixed programming [8], RFID technology selection [9], etc. Fuzzy set theory is used to manage the uncertainty in decision making and optimization problems, as ranking of fuzzy numbers is the most important part of decision process in these problems [10]. Since then, several types of fuzzy sets have been proposed such as intuitionistic fuzzy sets, interval-valued fuzzy sets, interval-valued intuitionistic fuzzy sets, hesitant fuzzy sets, type-2 fuzzy sets, and fuzzy multisets. These types have been used in scientific and real life problems.

In most cases, it is very difficult for a human to make a choice if it depends on some numerical factors. Therefore, decision making is very important in real life. Group decision making is a process to get the optimal solution from a set of solutions under certain criteria and the solutions are evaluated by 
multiple decision makers under that criteria. The decision makers can give their suggestions in the form of preference of solutions and also provide the comparison between one solution and another solution, this kind of comparison is called preference relation. Preference relation is a great tool to model decision making problems and is used to represent decision making problems [11]. Different kinds of preference relations have been proposed, for example multiplicative fuzzy preference relations [12], incomplete fuzzy preference relations [13], interval fuzzy preference relations [14], intuitionistic fuzzy preference relations, and hesitant fuzzy preference relations $[15,16]$. Many researchers have applied different fuzzy preference relationship methods to solve decision making problems $[8,9]$. These methods include the multiplicative preference relationship [17], the triangular multiplicative fuzzy preference relationship [18], and multiplicative consistent fuzzy preference relations [19]. As a result of a lack of knowledge, a shortage of time, and an unavailability of data resources decision makers often provide their preferences in the form of numerical values. To handle such situations, we proposed and solved the fuzzy preference relations. The fuzzy preference relation model refers to choosing the best solution from the feasible solution set $X=\left(x_{1}, x_{2}, \ldots, x_{n}\right)$ where $n \geq 2$. The key problem in fuzzy set theory is how to rank the fuzzy numbers. The ranking method for fuzzy numbers was first presented by Jain in 1976 [20]. Yao and Wu introduced a ranking method for fuzzy numbers based on the decomposition principle [21]. Later Gu and Xuan proposed a ranking method for generalized L-R fuzzy numbers based on possibility theory [22].

From the above studies, researchers have applied fuzzy set theory or preference relation theory to the evaluation of decision-making problems. On the basis of the preference relationship of the decision analysis process, the basic method is to get its priority by integrating the preference information of the alternative properties. In the decision-making process, the preference value in the preference relationship must satisfy the logical form of thinking. However, traditional multi-criteria decision-making methods are generally only applicable to the small number of decision-makers, how to use this decision-making method to deal with the public participation in public project decision-making issues, and the existing results have relatively little research in this field. Some scholars adopt the method of clustering the public group first and then evaluating it, which is a more reasonable and feasible way to deal with the problem of public group in the known method. The order of preference items of different groups to be solved in this paper is also related to the public group, but it has definite group classification. Therefore, this study does not need to conduct pre-decision-making clustering work, as long as the different user groups examine the preference information, the fuzzy preference relationship ranking model for decision making can be built.

In this paper, the Nature Reserve of Dangshan Pear Germplasm Resources was selected as the research location, and experts and representatives of different roles (government, farmers, and tourists) were invited to give the fuzzy preference relation coefficients. Then, the fuzzy preference relations model was proposed and solved using the Lagrange function to obtain the ranking values of the user preference recommendation function. Finally, the results of sorting were applied to the precision management of the Nature Reserve of Dangshan Pear Germplasm Resources.

The paper is organized as follows. In Section 1, previous work is presented. Section 2 discusses the ranking method based on fuzzy preference relations for user recommendation. Section 3 contains the requirements analyses, data collection, experiments results and analyses. Section 4 concludes the paper and gives the future prospects.

\section{Ranking Model for Alternatives Based on Fuzzy Preference Relations}

The human decision making process is a process of the interpretation of people's evaluation and selection of things. The priority of the items to be sorted is difficult to distinguish with distinct boundaries. Fuzzy logic can be well used to reflect the thinking process of people analyzing and dealing with things. Therefore, in the process of decision analysis, the fuzzy preference information of decision-makers often needs to be considered. The preference information of decision makers for attributes or alternatives is generally expressed as a preference relation matrix. Because the ranking of 
the main features in the reserve is a complex decision-making problem, it is often difficult for different groups to give the ranking results of the main features in the reserve directly. However, it is easy for users to compare the priority of two items, so the preference relation matrix is suitable for describing the preference information of different groups to the main features in the reserve.

The approach for the user recommendation projects in the reserve is to select the optimal solution from a limited set of project-sorting solutions, such as $X=\left(x_{1}, x_{2}, \ldots, x_{n}\right)(n \geq 2)$. In the process of project sorting, the decision information used in the model is a kind of fuzzy preference relation that users provide about the sorting scheme. On the basis of the fuzzy preference relation and the requirements of reserve management, the preference ranking model of different user groups to the main features in the reserve was established. Users provided some information which is a type of fuzzy preference relations. We used a fuzzy relation matrix $P$ to represent the fuzzy preference relations, where $P \subset X \times X$. The corresponding membership function is $\mu_{p}: X \times X^{\rightarrow}[0,1]$ where $\mu_{p}\left(X_{i}, X_{j}\right)=P_{i j}$, which indicates that the item $x$ is superior to the preference degree of the item $y$. is a decimal between 0 and 1. Matrix $P=\left[P_{i j}\right]_{n \times n}$ is complementary matrix, that is to say $\forall i, j$, $P_{i j}+P_{j i}=1, P_{i j} \geq 0, P_{i i}=0.5$.

On the basis of the above-mentioned fuzzy preference relations, we propose a ranking model for user recommendation projects.

Suppose that the ranking result of the user recommendation project $X$ is $D$, where $D=$ $\left(d_{1}, d_{2}, \ldots, d_{n}\right)^{T}, d_{i} \geq 0, \sum_{i=1}^{n} d_{i}=1$. In order to obtain the value of $D$, the following approximate relational expression is expected:

$$
P_{i j} \approx \frac{d_{i}}{d_{i}+d_{j}}, i, j=1,2,3, \ldots, n
$$

It can be seen that the larger the value of $d_{i}$, the larger the value of $P_{i j}$. Therefore, the following optimization model with constraints based on the relationship between $P_{i j}$ and $d_{i}$ is proposed.

$$
\begin{array}{ll}
\text { Min: } \quad & z=\sum_{\substack{i=1 \\
j=1 \\
j \neq i}}^{n} \sum^{n}\left[\left(d_{i}-\left(d_{i}+d_{j}\right)\right) p_{i j}\right]^{2} \\
\text { s.t.: } \quad & \sum_{j=1}^{n} d_{j}=1 \\
& d_{j} \geq 0, j=1,2,3, \ldots, n
\end{array}
$$

In order to analyze conveniently, the above model can be transformed to the following ones:

$$
\begin{array}{ll}
\text { Model Input: } & P=\left[P_{i j}\right]_{n \times n^{\prime}} 0 \leq P_{i j} \leq 1, P_{i j}=1-P_{j i} \\
\text { Contents of model: } & \text { Min: } \quad z=D^{T} Q D \\
\text { s.t.: } & e^{T} D=1 \\
\text { Explanation: } & D=\left(d_{1}, d_{2}, \ldots, d_{n}\right)^{T}, \\
& e=(1,1,1, \ldots, 1)^{T}, \\
& Q=\left[q_{i j}\right]_{n \times n^{2}} \\
& q_{i i}=2 \sum_{\substack{k=0 \\
k \neq i}}^{n} P_{k i}^{2}, \quad i=1,2, \ldots, n \\
& q_{i j}=2\left(P_{i j}^{2}-P_{i j}\right), i=1,2, \ldots, n ; i \neq j
\end{array}
$$


We established a Lagrangian function to solve the proposed optimization model. The solution process is shown below. The flowchart of the model is shown in Figure 2, and the solution process is given below.

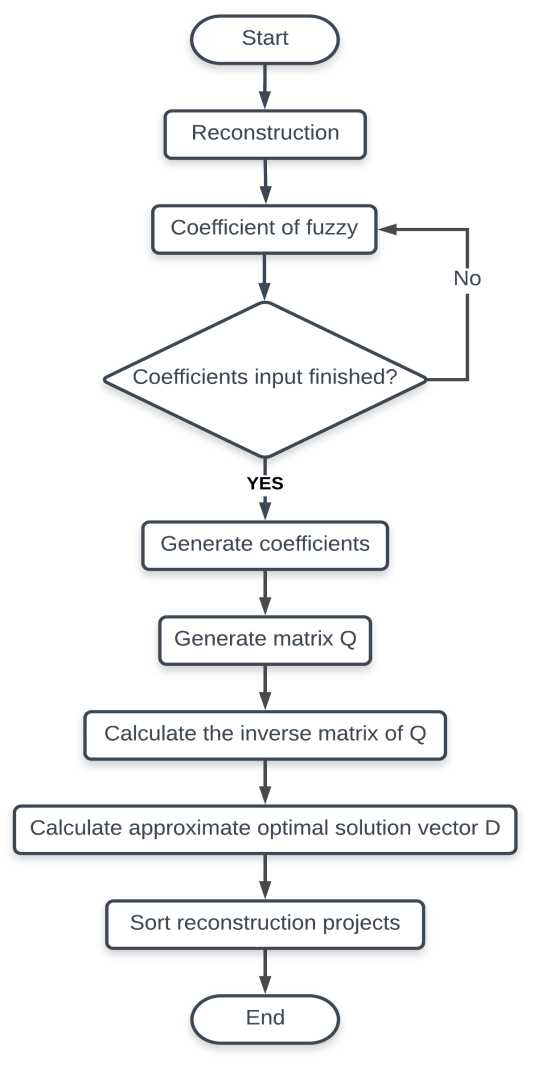

Figure 2. Flowchart of the ranking model.

Set the Lagrangian function to be $L$.

$$
\begin{gathered}
L=D^{T} Q D+2 \alpha\left(e^{T} D-1\right) \quad(\text { where } \alpha \text { is the Lagrangian multiplier) } \\
\frac{\partial L}{\partial D}=0 \Rightarrow 2 Q D+2 \alpha e=0 \\
\frac{\partial L}{\partial \alpha}=0 \Rightarrow 2 e^{T} D=2
\end{gathered}
$$

$$
\text { Equation }(1) \Rightarrow D=-Q^{-1} \alpha e
$$

Use Equation (3) into Equation (2) $\Rightarrow-e^{T} Q^{-1} \alpha e=1$

$$
\therefore \quad \alpha=\frac{-1}{e^{T} Q^{-1} e}
$$




$$
\text { Use Equation (4) into Equation (3) } \Rightarrow D=\frac{Q^{-1} e}{e^{T} Q^{-1} e}
$$

From Equation (5), we can find the value of the approximate optimal solution $D$. Model output is vector $D$ (the ranking vector of recommended projects):

$$
\begin{aligned}
& D=\left[d_{j}\right]_{n^{\prime}}, d_{j} \geq 0, \\
& \sum_{j=1}^{n} d_{j}=1 .
\end{aligned}
$$

Through the above analysis, programming languages can be used to solve the proposed model. We applied MATLAB to perform experiments and solved the proposed models.

\section{Requirements Analyses and Data Collection}

To test the model, we selected the "Dangshan Pear Germplasm Resources Nature Reserve" as the research location. By going through relevant documents and with government assistance, we launched a survey of the local ecological environment, geography, and living status to determine the main user preference recommendations. Then, we consulted the relevant experts and representatives of the different roles (government, farmers, and tourists) and collected their preferences using questionnaires. Finally, we used the collected data for the project sorting experiment.

\subsection{Design of the Survey Table}

We referred to China's official documents on agriculture, with a special focus on forestry. These documents include the relevant regulations on the Measures for the Administration of the Protection of Old and Famous Trees in Cities, which was formulated and promulgated on 1 September 2000, by the Ministry of Construction of the People's Republic of China. The ordinance clearly stated that "old trees" refers to trees that are over a hundred years old. "Famous trees" refers to rare plants both in China and abroad, as well as trees with historical significance, memorial significance, or important scientific research value. On the basis of the implementation of protection and management of forest trees, the living conditions of residents, and tourists' sightseeing requirements, we selected three different roles: government regulation, farmers, and tourists. From these different roles, we determined different user preferences. Finally, we divided the recommended projects into seven categories: Dangshan pear germplasm resources; native variety and new variety resources of Dangshan pear; other fruit species resources; woodland; water; animal protection area; industrial and mining enterprises. Table 1 describes the mentioned categories.

\subsection{Statistical Analysis}

For each role category (government, farmers, and tourists), we invited five experts or users to determine the fuzzy priority relationship coefficient through the implementation of a questionnaire.

\subsubsection{Government Regulatory Role Survey Data}

Firstly, we investigated the role of government regulation. We invited experts on ancient and famous trees and local environmental protection agencies to conduct a survey. The survey data are shown in Table 2, where names of the five experts are replaced with $A, B, C, D$, and E, and the priority of projects $p_{1}$ to $p_{2}$ is denoted by " $p_{1}$ vs. $p_{2}{ }^{\prime \prime}$; moreover, $\left(p_{2}\right.$ vs. $\left.p_{1}\right)=1-\left(p_{1}\right.$ vs. $\left.p_{2}\right)$. 
Table 1. Recommended project categories.

\begin{tabular}{|c|c|c|}
\hline Category & Keyword & Content \\
\hline \multirow{5}{*}{$\begin{array}{l}\text { Dangshan pear } \\
\text { germplasm } \\
\text { resources }\end{array}$} & $\begin{array}{l}\text { Growth situation and } \\
\text { growth environment of } \\
\text { pear tree in } \\
\text { Dangshan region }\end{array}$ & $\begin{array}{l}\text { No felling, natural death, update, grafting, tree integrity, } \\
\text { normal growth of leaf and fruit, growth of } \\
\text { windbreaks, trees. }\end{array}$ \\
\hline & $\begin{array}{l}\text { The production situation } \\
\text { of Dangshan pear }\end{array}$ & $\begin{array}{l}\text { Pruning, fertilization, irrigation, pest and farming } \\
\text { operations, etc. }\end{array}$ \\
\hline & Weather changes & Precipitation, cooling, wind, fog, drought, water, hail, etc. \\
\hline & $\begin{array}{l}\text { Abnormal phenomena } \\
\text { related to pear trees }\end{array}$ & Abnormal phenomena, such as pests, leaves, and fruit. \\
\hline & Genetic changes & $\begin{array}{l}\text { Bud strains change, observation of fruit growth, quality, } \\
\text { and maturity period. }\end{array}$ \\
\hline \multirow{2}{*}{$\begin{array}{l}\text { Native variety and } \\
\text { new variety } \\
\text { resources of } \\
\text { Dangshan pear }\end{array}$} & New varieties & $\begin{array}{l}\text { Distribution, growth status, biological characteristics, } \\
\text { specific growth and development, specific pest and } \\
\text { disease categories. }\end{array}$ \\
\hline & $\begin{array}{l}\text { Endangered pear } \\
\text { varieties }\end{array}$ & $\begin{array}{l}\text { Distribution, quantity, growth status, protection measures, } \\
\text { and biological characteristics. }\end{array}$ \\
\hline \multirow{3}{*}{$\begin{array}{l}\text { Other fruit species } \\
\text { resources }\end{array}$} & Apple varieties & $\begin{array}{l}\text { Distribution, fruit economic characters, biological } \\
\text { characteristics, main pests and diseases species, market } \\
\text { sale, etc. }\end{array}$ \\
\hline & Peach varieties & $\begin{array}{l}\text { Distribution, fruit economic characters, biological } \\
\text { characteristics, main pests and diseases species, market } \\
\text { sale etc. }\end{array}$ \\
\hline & Other fruit resources & Strawberry, grape, sugar cane, plum, etc. \\
\hline \multirow{5}{*}{ Woodland } & Main tree species & Distribution, scale and growth condition. \\
\hline & Forest ecosystem & $\begin{array}{l}\text { The main tree species, the auxiliary tree species, the other } \\
\text { plant species in the woodland, the growth situation, and } \\
\text { the degree of harmony. }\end{array}$ \\
\hline & Growth condition & $\begin{array}{l}\text { The growth of fruit tree wind forest, farmland windproof } \\
\text { forest, village forest, road tree, special timber forest, etc. }\end{array}$ \\
\hline & Protection condition & $\begin{array}{l}\text { The protection and growth of the key trees and } \\
\text { ancient trees. }\end{array}$ \\
\hline & Damage condition & Deforestation, renewal, destruction and pollution. \\
\hline Water & Environmental effects & $\begin{array}{l}\text { The area of water, the amount of water, the pollution } \\
\text { factor, the degree of pollution, the occupation, the species } \\
\text { of animals and plants in the water, etc. }\end{array}$ \\
\hline \multirow{2}{*}{$\begin{array}{l}\text { Animal protection } \\
\text { area }\end{array}$} & Birds & $\begin{array}{l}\text { Quantity, species, migration, and influence on other } \\
\text { resources in the protected area. }\end{array}$ \\
\hline & Other species of animals & Amphibians, aquatic animals (fish), zooplankton, etc. \\
\hline \multirow{3}{*}{$\begin{array}{l}\text { Industrial and } \\
\text { mining enterprises }\end{array}$} & $\begin{array}{l}\text { Nature reserve area } \\
\text { occupied by enterprises }\end{array}$ & $\begin{array}{l}\text { The name, scale, product and impact on protected } \\
\text { area resources. }\end{array}$ \\
\hline & Pollution & $\begin{array}{l}\text { The emission of pollutants and pollution, the impact on } \\
\text { the resources of the protected area, and the } \\
\text { protection measures. }\end{array}$ \\
\hline & Public infrastructure & $\begin{array}{l}\text { Other projects (such as road repair, river control, large } \\
\text { residential construction) have no EIA reports, pollution } \\
\text { level and control. }\end{array}$ \\
\hline
\end{tabular}


Table 2. Government regulatory role survey data.

\begin{tabular}{|c|c|c|c|c|c|c|}
\hline Priority between Projects & A & B & $\mathrm{C}$ & D & E & Average \\
\hline $\begin{array}{l}\text { Dangshan pear germplasm resources vs. Native variety } \\
\text { and new variety resources of Dangshan pear }\end{array}$ & 0.92 & 0.85 & 0.80 & 0.80 & 0.82 & 0.84 \\
\hline $\begin{array}{l}\text { Dangshan pear germplasm resources vs. Other fruit } \\
\text { species resources }\end{array}$ & 0.94 & 0.80 & 0.86 & 0.82 & 0.80 & 0.84 \\
\hline Dangshan pear germplasm resources vs. Woodland & 0.62 & 0.68 & 0.70 & 0.65 & 0.75 & 0.68 \\
\hline Dangshan pear germplasm resources vs. Water & 0.70 & 0.60 & 0.65 & 0.65 & 0.60 & 0.64 \\
\hline $\begin{array}{l}\text { Dangshan pear germplasm resources vs. Protected animal } \\
\text { area }\end{array}$ & 0.50 & 0.60 & 0.52 & 0.55 & 0.58 & 0.55 \\
\hline $\begin{array}{l}\text { Dangshan pear germplasm resources vs. Industrial and } \\
\text { mining enterprises }\end{array}$ & 0.56 & 0.62 & 0.65 & 0.60 & 0.50 & 0.58 \\
\hline $\begin{array}{l}\text { Native variety and new variety resources of Dangshan } \\
\text { pear vs. Other fruit species resources }\end{array}$ & 0.62 & 0.52 & 0.45 & 0.55 & 0.55 & 0.54 \\
\hline $\begin{array}{l}\text { Native variety and new variety resources of Dangshan } \\
\text { pear vs. Woodland }\end{array}$ & 0.35 & 0.55 & 0.42 & 0.40 & 0.30 & 0.40 \\
\hline $\begin{array}{l}\text { Native variety and new variety resources of Dangshan } \\
\text { pear vs. Water }\end{array}$ & 0.42 & 0.40 & 0.45 & 0.48 & 0.45 & 0.44 \\
\hline $\begin{array}{l}\text { Native variety and new variety resources of Dangshan } \\
\text { pear vs. Protected animal area }\end{array}$ & 0.30 & 0.25 & 0.45 & 0.35 & 0.40 & 0.35 \\
\hline $\begin{array}{l}\text { Native variety and new variety resources of Dangshan } \\
\text { pear vs. Industrial and mining enterprises }\end{array}$ & 0.35 & 0.45 & 0.37 & 0.40 & 0.40 & 0.39 \\
\hline Other fruit species resources vs. Woodland & 0.25 & 0.30 & 0.35 & 0.45 & 0.40 & 0.35 \\
\hline Other fruit species resources vs. Water & 0.40 & 0.35 & 0.30 & 0.45 & 0.45 & 0.39 \\
\hline Other fruit species resources vs. Protected animal area & 0.25 & 0.30 & 0.25 & 0.25 & 0.32 & 0.27 \\
\hline $\begin{array}{l}\text { Other fruit species resources vs. Industrial and } \\
\text { mining enterprises }\end{array}$ & 0.30 & 0.30 & 0.25 & 0.32 & 0.35 & 0.30 \\
\hline Woodland vs. Water & 0.55 & 0.50 & 0.60 & 0.55 & 0.60 & 0.56 \\
\hline Woodland vs. Protected animal area & 0.45 & 0.40 & 0.40 & 0.38 & 0.45 & 0.41 \\
\hline Woodland vs. Industrial and mining enterprises & 0.50 & 0.48 & 0.45 & 0.40 & 0.50 & 0.46 \\
\hline Water vs. Protected animal area & 0.30 & 0.40 & 0.25 & 0.30 & 0.35 & 0.32 \\
\hline Water vs. Industrial and mining enterprises & 0.35 & 0.30 & 0.30 & 0.30 & 0.40 & 0.33 \\
\hline $\begin{array}{l}\text { Protected animal area vs. Industrial and } \\
\text { mining enterprises }\end{array}$ & 0.50 & 0.45 & 0.65 & 0.50 & 0.55 & 0.53 \\
\hline
\end{tabular}

The evaluation data for the five experts was processed using the weighted average method. The final survey results are shown in Table 3.

The results in Table 3 form the fuzzy preference relation matrix. This matrix is the input of the ranking model for restoration and reconstruction projects. We applied Formula (5) to obtain the ranking results. These ranking results are shown in Table 4 .

From the ranking results in Table 4, it can be seen that Dangshan pear germplasm resources is ranked first, and animal protection area is ranked second. The ranking results reflect that government regulation mainly focuses on ancient rosewood, animal protection zones, and the ecological environment. 
Table 3. Government regulatory role survey results.

\begin{tabular}{|c|c|c|c|c|c|c|c|}
\hline Project & $\begin{array}{l}\text { Dangshan } \\
\text { Pear } \\
\text { Resources }\end{array}$ & $\begin{array}{c}\text { Varieties of } \\
\text { Dangshan } \\
\text { Pear }\end{array}$ & $\begin{array}{l}\text { Other } \\
\text { Fruit } \\
\text { Species } \\
\text { Resources }\end{array}$ & $\begin{array}{l}\text { Wood } \\
\text { Land }\end{array}$ & $\begin{array}{l}\text { Water } \\
\text { Body }\end{array}$ & $\begin{array}{c}\text { Protected } \\
\text { Animal } \\
\text { Area }\end{array}$ & $\begin{array}{c}\text { Industrial } \\
\text { and } \\
\text { Mining } \\
\text { Enterprises }\end{array}$ \\
\hline Varieties of Dangshan Pear & 0.16 & 0.50 & 0.54 & 0.40 & 0.44 & 0.35 & 0.39 \\
\hline Other fruit species resources & 0.15 & 0.46 & 0.50 & 0.35 & 0.39 & 0.27 & 0.30 \\
\hline Woodland & 0.32 & 0.59 & 0.65 & 0.50 & 0.56 & 0.42 & 0.47 \\
\hline Protected animal area & 0.45 & 0.65 & 0.72 & 0.58 & 0.68 & 0.50 & 0.53 \\
\hline Industrial and mining enterprises & 0.41 & 0.60 & 0.69 & 0.53 & 0.67 & 0.47 & 0.50 \\
\hline
\end{tabular}

Table 4. Ranking results of government regulatory role.

\begin{tabular}{lccc}
\hline \multicolumn{1}{c}{ Ranking Results } & \multirow{2}{*}{ Priority } & \multirow{2}{*}{ Ranking } \\
\hline Project & & 0.25 & 1 \\
Native variety and new variety resources of Dangshan pear & 0.08 & 6 \\
Other fruit species resources & 0.66 & 7 \\
Woodland & 0.13 & 4 \\
Water body & 0.10 & 5 \\
Protected animal area & 0.19 & 2 \\
Industrial and mining enterprises & 0.17 & 3 \\
\hline
\end{tabular}

\subsubsection{Farmers' Role Survey Data}

During the second stage of the survey, we investigated the farmers and local residents in the Nature Reserve of Dangshan Pear Germplasm Resources by inviting them to carry out a questionnaire; the survey data are shown in Table 5, where names of the five experts are replaced with A, B, C, D, and E, and the priority of projects $p_{1}$ to $p_{2}$ is denoted by " $p_{1}$ vs. $p_{2}{ }^{\prime \prime} ;$ moreover, $\left(p_{2}\right.$ vs. $\left.p_{1}\right)=1-\left(p_{1}\right.$ vs. $\left.p_{2}\right)$.

Table 5. Survey data on the role of farmers.

\begin{tabular}{|c|c|c|c|c|c|c|}
\hline Priority between Projects & $\mathbf{A}$ & B & $\mathrm{C}$ & D & E & Average \\
\hline \multicolumn{7}{|l|}{ Expert } \\
\hline $\begin{array}{l}\text { Dangshan pear germplasm resources vs. Other fruit species } \\
\text { resources }\end{array}$ & 0.60 & 0.55 & 0.60 & 0.65 & 0.60 & 0.60 \\
\hline Dangshan pear germplasm resources vs. Woodland & 0.75 & 0.80 & 0.75 & 0.72 & 0.75 & 0.75 \\
\hline Dangshan pear germplasm resources vs. Water & 0.78 & 0.80 & 0.85 & 0.78 & 0.80 & 0.80 \\
\hline $\begin{array}{l}\text { Dangshan pear germplasm resources vs. Protected animal } \\
\text { area }\end{array}$ & 0.85 & 0.85 & 0.88 & 0.82 & 0.85 & 0.85 \\
\hline $\begin{array}{l}\text { Native variety and new variety resources of Dangshan pear } \\
\text { vs. Woodland }\end{array}$ & 0.68 & 0.70 & 0.65 & 0.65 & 0.70 & 0.67 \\
\hline $\begin{array}{l}\text { Native variety and new variety resources of Dangshan pear } \\
\text { vs. Water }\end{array}$ & 0.75 & 0.72 & 0.70 & 0.78 & 0.75 & 0.74 \\
\hline $\begin{array}{l}\text { Native variety and new variety resources of Dangshan pear } \\
\text { vs. Protected animal area }\end{array}$ & 0.80 & 0.82 & 0.80 & 0.85 & 0.82 & 0.82 \\
\hline $\begin{array}{l}\text { Native variety and new variety resources of Dangshan pear } \\
\text { vs. Industrial and mining enterprises }\end{array}$ & 0.60 & 0.62 & 0.60 & 0.62 & 0.65 & 0.62 \\
\hline
\end{tabular}


Table 5. Cont

\begin{tabular}{lcccccc}
\hline \multicolumn{1}{c}{ Priority between Projects } & A & B & C & D & E & Average \\
Expert & & & & & & \\
\hline Other fruit species resources vs. Woodland & 0.60 & 0.58 & 0.65 & 0.65 & 0.62 & 0.62 \\
\hline Other fruit species resources vs. Water & 0.75 & 0.70 & 0.65 & 0.68 & 0.70 & 0.69 \\
\hline Other fruit species resources vs. Protected animal area & 0.70 & 0.78 & 0.80 & 0.75 & 0.75 & 0.75 \\
\hline $\begin{array}{l}\text { Other fruit species resources vs. Industrial and mining } \\
\text { enterprises }\end{array}$ & 0.55 & 0.58 & 0.60 & 0.52 & 0.52 & 0.55 \\
\hline Woodland vs. Water & 0.56 & 0.58 & 0.55 & 0.58 & 0.55 & 0.56 \\
\hline Woodland vs. Protected animal area & 0.50 & 0.60 & 0.65 & 0.70 & 0.60 & 0.64 \\
\hline Woodland vs. Industrial and mining enterprises & 0.45 & 0.40 & 0.42 & 0.40 & 0.42 & 0.44 \\
\hline Water vs. Protected animal area & 0.40 & 0.42 & 0.45 & 0.40 & 0.42 & 0.42 \\
\hline Water vs. Industrial and mining enterprises & 0.36 & 0.35 & 0.38 & 0.36 & 0.38 & 0.366 \\
\hline Protected animal area vs. Industrial and mining enterprises & 0.28 & 0.25 & 0.25 & 0.35 & 0.30 & 0.36 \\
\hline
\end{tabular}

The evaluation data for the five experts was processed by the weighted average method. By using Formula (5), we obtained the sorting results. The final survey results are shown in Table 6.

Table 6. Results of the survey of farmers' roles.

\begin{tabular}{|c|c|c|c|c|c|c|c|}
\hline Project & $\begin{array}{c}\text { Dangshan } \\
\text { Pear } \\
\text { Resources }\end{array}$ & $\begin{array}{c}\text { Varieties of } \\
\text { Dangshan } \\
\text { Pear }\end{array}$ & $\begin{array}{l}\text { Other Fruit } \\
\text { Species } \\
\text { Resources }\end{array}$ & $\begin{array}{l}\text { Wood } \\
\text { Land }\end{array}$ & $\begin{array}{l}\text { Water } \\
\text { Body }\end{array}$ & $\begin{array}{c}\text { Protected } \\
\text { Animal } \\
\text { Areas }\end{array}$ & $\begin{array}{c}\text { Industrial } \\
\text { and } \\
\text { Mining } \\
\text { Enterprises }\end{array}$ \\
\hline Dangshan Pear Resources & 0.50 & 0.54 & 0.60 & 0.75 & 0.80 & 0.85 & 0.64 \\
\hline Varieties of Dangshan Pear & 0.45 & 0.50 & 0.55 & 0.67 & 0.74 & 0.82 & 0.62 \\
\hline Other fruit species resources & 0.40 & 0.45 & 0.50 & 0.62 & 0.69 & 0.75 & 0.55 \\
\hline Woodland & 0.24 & 0.32 & 0.38 & 0.50 & 0.56 & 0.64 & 0.44 \\
\hline Water body & 0.20 & 0.26 & 0.30 & 0.43 & 0.50 & 0.42 & 0.36 \\
\hline Protected animal area & 0.15 & 0.19 & 0.24 & 0.36 & 0.58 & 0.50 & 0.28 \\
\hline Industrial and mining enterprises & 0.35 & 0.38 & 0.44 & 0.56 & 0.63 & 0.71 & 0.50 \\
\hline
\end{tabular}

The results in Table 6 form the fuzzy preference relation matrix. This matrix is the input of the ranking model for restoration and reconstruction projects. The ranking results are shown in Table 7.

Table 7. Ranking results of farmers' roles.

\begin{tabular}{lccc}
\hline \multicolumn{1}{c}{ Ranking Results } & \multirow{2}{*}{ Priority } & \multirow{2}{*}{ Ranking } \\
\cline { 1 - 1 } Project & & 0.26 & 1 \\
Dative variety and new variety resources of Dangshan pear & 0.21 & 2 \\
Other fruit species resources & 0.17 & 3 \\
Woodland & 0.09 & 5 \\
Water body & 0.07 & 6 \\
Protected animal area & 0.05 & 7 \\
Industrial and mining enterprises & 0.13 & 4 \\
\hline
\end{tabular}

From Table 7, it can be seen that the Dangshan pear germplasm resources project is ranked first, and Dangshan local pear varieties and new varieties is ranked second. The ranking results reflect the local residents being more concerned about the output of fruit trees and the introduction of new local varieties.

\subsubsection{Tourist Role Survey Data}

At the end of the survey process, we invited visitors who came to visit the Nature Reserve of Dangshan Pear Germplasm Resources to carry out a questionnaire survey. The survey data are shown 
in Table 8, where names of the five experts are replaced with A, B, C, D, and E, and the priority of projects $p_{1}$ to $p_{2}$ is denoted by " $p_{1}$ vs. $p_{2}{ }^{\prime \prime} ;$ moreover, $\left(p_{2}\right.$ vs. $\left.p_{1}\right)=1-\left(p_{1}\right.$ vs. $\left.p_{2}\right)$.

Table 8. Tourist role survey data.

\begin{tabular}{|c|c|c|c|c|c|c|}
\hline $\begin{array}{ll}\text { Expert } & \text { Priority between Projects } \\
\end{array}$ & A & B & $\mathrm{C}$ & $\mathbf{D}$ & $\mathbf{E}$ & Average \\
\hline $\begin{array}{l}\text { Dangshan pear germplasm resources vs. Native variety } \\
\text { and new variety resources of Dangshan pear }\end{array}$ & 0.75 & 0.70 & 0.70 & 0.75 & 0.78 & 0.73 \\
\hline $\begin{array}{l}\text { Dangshan pear germplasm resources vs. Other fruit } \\
\text { species resources }\end{array}$ & 0.80 & 0.75 & 0.78 & 0.78 & 0.80 & 0.78 \\
\hline Dangshan pear germplasm resources vs. Woodland & 0.70 & 0.65 & 0.70 & 0.60 & 0.62 & 0.65 \\
\hline Dangshan pear germplasm resources vs. Water & 0.85 & 0.78 & 0.80 & 0.78 & 0.80 & 0.80 \\
\hline $\begin{array}{l}\text { Dangshan pear germplasm resources vs. Protected } \\
\text { animal area }\end{array}$ & 0.55 & 0.50 & 0.60 & 0.52 & 0.52 & 0.54 \\
\hline $\begin{array}{l}\text { Dangshan pear germplasm resources vs. Industrial and } \\
\text { mining enterprises }\end{array}$ & 0.85 & 0.85 & 0.80 & 0.82 & 0.78 & 0.82 \\
\hline $\begin{array}{l}\text { Native variety and new variety resources of Dangshan } \\
\text { pear vs. Other fruit species resources }\end{array}$ & 0.55 & 0.52 & 0.55 & 0.58 & 0.60 & 0.56 \\
\hline $\begin{array}{l}\text { Native variety and new variety resources of Dangshan } \\
\text { pear vs. Woodland }\end{array}$ & 0.45 & 0.42 & 0.40 & 0.48 & 0.50 & 0.45 \\
\hline $\begin{array}{l}\text { Native variety and new variety resources of Dangshan } \\
\text { pear vs. Water }\end{array}$ & 0.70 & 0.62 & 0.68 & 0.72 & 0.75 & 0.69 \\
\hline $\begin{array}{l}\text { Native variety and new variety resources of Dangshan } \\
\text { pear vs. Protected animal area }\end{array}$ & 0.30 & 0.32 & 0.35 & 0.35 & 0.32 & 0.33 \\
\hline $\begin{array}{l}\text { Native variety and new variety resources of Dangshan } \\
\text { pear vs. Industrial and mining enterprises }\end{array}$ & 0.75 & 0.78 & 0.80 & 0.78 & 0.70 & 0.76 \\
\hline Other fruit species resources vs. Woodland & 0.30 & 0.35 & 0.28 & 0.32 & 0.32 & 0.42 \\
\hline Other fruit species resources vs. Water & 0.55 & 0.52 & 0.60 & 0.60 & 0.55 & 0.56 \\
\hline Other fruit species resources vs. Protected animal area & 0.22 & 0.28 & 0.20 & 0.22 & 0.35 & 0.25 \\
\hline $\begin{array}{l}\text { Other fruit species resources vs. Industrial and mining } \\
\text { enterprises }\end{array}$ & 0.75 & 0.70 & 0.72 & 0.66 & 0.68 & 0.70 \\
\hline Woodland vs. Water & 0.72 & 0.75 & 0.72 & 0.76 & 0.80 & 0.75 \\
\hline Woodland vs. Protected animal area & 0.45 & 0.42 & 0.40 & 0.60 & 0.40 & 0.45 \\
\hline Woodland vs. Industrial and mining enterprises & 0.80 & 0.82 & 0.75 & 0.80 & 0.80 & 0.79 \\
\hline Water vs. Protected animal area & 0.25 & 0.18 & 0.20 & 0.20 & 0.22 & 0.21 \\
\hline Water vs. Industrial and mining enterprises & 0.58 & 0.52 & 0.62 & 0.55 & 0.58 & 0.57 \\
\hline $\begin{array}{l}\text { Protected animal area vs. Industrial and } \\
\text { mining enterprises }\end{array}$ & 0.80 & 0.82 & 0.80 & 0.78 & 0.85 & 0.81 \\
\hline
\end{tabular}

The evaluation data for the five experts was processed by the weighted average method. The final survey results are shown in Table 9.

Table 9. Survey results of tourist roles.

\begin{tabular}{|c|c|c|c|c|c|c|c|}
\hline Project & $\begin{array}{c}\text { Dangshan } \\
\text { Pear } \\
\text { Resources }\end{array}$ & $\begin{array}{c}\text { Varieties of } \\
\text { Dangshan } \\
\text { Pear }\end{array}$ & $\begin{array}{l}\text { Other Fruit } \\
\text { Species } \\
\text { Resources }\end{array}$ & $\begin{array}{l}\text { Wood } \\
\text { Land }\end{array}$ & $\begin{array}{l}\text { Water } \\
\text { Body }\end{array}$ & $\begin{array}{c}\text { Protected } \\
\text { Animals } \\
\text { Area }\end{array}$ & $\begin{array}{c}\text { Industrial } \\
\text { and } \\
\text { Mining } \\
\text { Enterprises }\end{array}$ \\
\hline Dangshan Pear Resources & 0.50 & 0.73 & 0.78 & 0.65 & 0.80 & 0.54 & 0.82 \\
\hline Varieties of Dangshan Pear & 0.26 & 0.50 & 0.56 & 0.45 & 0.69 & 0.33 & 0.76 \\
\hline Other fruit species resources & 0.22 & 0.44 & 0.50 & 0.42 & 0.56 & 0.25 & 0.70 \\
\hline Woodland & 0.34 & 0.55 & 0.58 & 0.50 & 0.75 & 0.45 & 0.79 \\
\hline Water body & 0.20 & 0.31 & 0.43 & 0.25 & 0.50 & 0.21 & 0.57 \\
\hline Protected animal area & 0.46 & 0.67 & 0.74 & 0.54 & 0.79 & 0.50 & 0.81 \\
\hline Industrial and mining enterprises & 0.18 & 0.24 & 0.30 & 0.21 & 0.43 & 0.19 & 0.50 \\
\hline
\end{tabular}


The results in Table 9 form the fuzzy preference relation matrix. This matrix is the input of the ranking model for restoration and reconstruction projects. We obtained the ranking results. These ranking results are shown in Table 10.

Table 10. Ranking results of tourist roles.

\begin{tabular}{lccc}
\hline \multicolumn{1}{c}{ Ranking Results } & \multirow{2}{*}{ Priority } & \multirow{2}{*}{ Ranking } \\
\hline Project & & 0.29 & 1 \\
Native variety and new variety resources of Dangshan pear & 0.12 & 4 \\
Other fruit species resources & 0.09 & 5 \\
Woodland & 0.16 & 3 \\
Water body & 0.06 & 6 \\
Protected animal area & 0.23 & 2 \\
Industrial and mining enterprises & 0.05 & 7 \\
\hline
\end{tabular}

From the ranking results in Table 10, it is seen that Dangshan pear germplasm resources is ranked first, and animal protection area is ranked second. The results of the rankings show that tourists are most concerned about scenic spots with higher ornamental value in the protected areas. Visitors can use the user preference ordering function to choose scenic spots for themselves. Therefore, in the future, we can recommend scenic spots to tourists according to the sorting results.

\subsubsection{Result Analysis and Discussion}

The Nature Reserve of Dangshan Pear Germplasm Resources is an open area sustained for the protection of pear Germplasm resources, over 100 year old pear trees, biodiversity, and the wetland ecosystem. It is not only the government who manages the reserve, but also local farmers who produce fruit trees, as well as tourists who visit the nature reserve. The questionnaire data were collected by classification according to the three roles of government regulation, farmers, and tourists. The data were processed to get the fuzzy preference relationship coefficients of the different roles, and finally, the ranking value of the recommended items for various user preferences was obtained. We selected the first three preference features from the above experimental results and compared them with each other. The first three preferences for each role are shown in Table 11.

Table 11. First three preference objects of the experiments.

\begin{tabular}{|c|c|c|c|}
\hline $\begin{array}{ll} & \text { Preference Objects } \\
\text { Users } & \end{array}$ & Rank First & Rank Second & Rank Third \\
\hline Government & $\begin{array}{c}\text { Dangshan Pear } \\
\text { Resources }\end{array}$ & Protected animal area & $\begin{array}{l}\text { Industrial and mining } \\
\text { enterprises }\end{array}$ \\
\hline Farmers & $\begin{array}{c}\text { Dangshan Pear } \\
\text { Resources }\end{array}$ & $\begin{array}{l}\text { Native variety and new } \\
\text { variety resources of } \\
\text { Dangshan pear }\end{array}$ & $\begin{array}{c}\text { Other fruit } \\
\text { species resources }\end{array}$ \\
\hline Tourists & $\begin{array}{c}\text { Dangshan Pear } \\
\text { Resources }\end{array}$ & Protected animal area & Woodland \\
\hline
\end{tabular}

The top three items that the government are most concerned about are the Dangshan Pear Resources, the protected animal area, and the industrial and mining enterprises. Because the main protection features of this reserve are the Dangshan pear germplasm resources, the over 100 year old pear resources, the biodiversity, and the wetland ecosystem represented by the Dangshan crisp pear. Therefore, the government is most concerned about Dangshan Pear Resources because they are the most important features of this nature reserve and also the most important protected features. The "protected animal area" is ranked second because biodiversity and the wetland ecosystem of the old Yellow River are also the core protected features of this nature reserve. "Industrial and mining 
enterprises" are ranked third because they have the biggest environmental impact on the protected areas and need to be closely monitored.

The top three items that farmers are most concerned about are the Dangshan Pear Resources, the native variety and new variety resources of Dangshan pear, and other fruit species resources. Farmers in the reserve are mainly local farmers from the 17 villages under the jurisdiction of the reserve. They carry out daily production activities with fruit trees in the reserve. Therefore, farmers firstly care about the Dangshan Pear Resources, because it contains Dangshan pear's precious varieties and brand effect. It is also the pride of the local farmers. The native variety and new variety resources of Dangshan pear ranks second because fruit trees planted by farmers are mostly of the native variety and new variety resources of Dangshan pear, which is directly related to local farmers' income. Other fruit species resources are ranked third because they are also the target of local farmers' agricultural production, such as Dangshan yellow peach, although not comparable to Dangshan pear, but also directly related to the income of local farmers.

The top three items that tourists are most concerned about are the Dangshan Pear Resources, the protected animal area, and the woodland. Because tourists are mainly attracted to the special resources and scenery in the nature reserve. Therefore, tourists firstly care about the Dangshan Pear Resources, because they contain tens of thousands of ancient Dangshan pear trees, which is the most attractive feature for tourists visiting this nature reserve. The protected animal area ranks second because tourists are generally interested in wildlife, especially teenagers and their parents, who may be more interested in wild swans than centuries-old Dangshan pear trees. The woodland ranks third because it is not only an escape to the noisy city, but the fresh air and scenery of the forest also greatly attract them.

To sum up, it can be seen that the ranking model in this paper combined with the survey data, which gives the project ranking results, are in line with the preferences of the users of different roles. Therefore, the results are of practical value.

\section{Conclusions and Future Prospects}

With the advancements in the information era, China's agricultural information technology has been continuously improving. To achieve the goal of applying better information technology to agricultural management, we need to develop better models to improve the management systems. In order to improve the information level of agricultural management, a ranking method based on fuzzy preference relations for user recommendation was proposed. We selected the Nature Reserve of Dangshan Pear Germplasm Resources as the research location and invited experts and representatives of different roles (government, farmers, and tourists) to give the fuzzy preference relationship coefficients of the user preference recommendation function. Then, an optimization model was proposed based on the fuzzy preference relations. The model was solved by constructing a Lagrangian function, and the ranking values of the user preference recommendation function were obtained. Finally, we ranked the order of the given roles and implemented the fuzzy preference recommendation. The experiments show that this proposed method is easy to implement, consistent, and effective. The experimental results are effective and in line with the actual situation.

In the future, we will expand the survey respondents, collect a wider range of data, and conduct further experiments to get more realistic survey results. We will aim to expand the optimization model to adapt it to other forms of preference relations, for example, those of conditional probability or interval number. We will also compare this method with other existing ranking methods.

Author Contributions: A.M. and Q.S. equally contributed to the design and implementation of the project, to the analysis of the results and to the writing of the manuscript. X.W. worked on the manuscript. X.Z. supervised the project, verified the numerical results and contributed to the final version of the manuscript.

Funding: This work was supported by the National Key Research and Development Program of China under Grant 2017YFD0301303 and the Qinghai Science and Technology Plan Project 2016-ZJ-607.

Conflicts of Interest: The authors declare no conflict of interest. 


\section{References}

1. Mcbratney, A.; Whelan, B.; Ancev, T.; Bouma, J. Future Directions of Precision Agriculture. Precis. Agric. 2005, 6, 7-23. [CrossRef]

2. Banu, S. Precision Agriculture: Tomorrow's Technology for Today's Farmer. J. Food Process. Technol. 2015, 6. [CrossRef]

3. Li, T. Cloud-based Decision Support and Automation for Precision Agriculture in Orchards. IFAC Papersonline 2016, 49, 330-335.

4. Lakshmana, G.N.V.; Muralikrishnan, S.; Sivaraman, G. Multi-criteria decision-making method based on interval-valued intuitionistic fuzzy sets. Expert Syst. Appl. 2018, 38, 1-18.

5. Banaeian, N.; Mobli, H.; Fahimnia, B.; Nielsen, I.E.; Omid, M. Green Supplier Selection Using Fuzzy Group Decision Making Methods: A Case Study from the Agri-Food Industry. Comput. Oper. Res. 2018, 89, 337-347. [CrossRef]

6. Pahlavani, A. A Hybrid Algorithm of Improved Case-Based Reasoning and Multi-Attribute Decision Making in Fuzzy Environment for Investment Loan Evaluation. Int. J. Inf. Decis. Sci. 2017, 2, 17-49. [CrossRef]

7. Capuano, N.; Loia, V.; Orciuoli, F. A Fuzzy Group Decision Making Model for Ordinal Peer Assessment. IEEE Trans. Learn. Technol. 2017, 10, 247-259. [CrossRef]

8. Meng, F.; Tang, J.; Xu, Z. A 0-1 mixed programming model based method for group decision making with intuitionistic fuzzy preference relations. Comput. Ind. Eng. 2017, 112, 289-304. [CrossRef]

9. Wan, S.P.; Wang, F.; Dong, J.Y. A novel group decision making method with intuitionistic fuzzy preference relations for RFID technology selection. Appl. Soft Comput. 2016, 38, 405-422. [CrossRef]

10. Chutia, R.; Chutia, B. A new method of ranking parametric form of fuzzy numbers using value and ambiguity. Appl. Soft Comput. 2017, 52, 1154-1168. [CrossRef]

11. Zhu, B.; Xu, Z.; Xu, J. Deriving a Ranking from Hesitant Fuzzy Preference Relations under Group Decision Making. IEEE Trans. Cybern. 2017, 44, 1328-1337. [CrossRef] [PubMed]

12. Chiclana, F.; Herrera, F.; Herrera-Viedma, E. Integrating multiplicative preference relations in a multipurpose decision-making model based on fuzzy preference relations. Fuzzy Sets Syst. 2001, 122, 277-291. [CrossRef]

13. Herrera-Viedma, E.; Alonso, S.; Chiclana, F.; Herrera, F. A consensus model for group decision making with incomplete fuzzy preference relations. IEEE Trans. Fuzzy Syst. 2007, 15, 863-877. [CrossRef]

14. Wan, S.P.; Wang, F.; Xu, G.L.; Dong, J.Y.; Tang, J. An intuitionistic fuzzy programming method for group decision making with interval-valued fuzzy preference relations. Fuzzy Optim. Decis. Mak. 2017, 16, 269-295. [CrossRef]

15. Liao, H.; Xu, Z. Priorities of Intuitionistic Fuzzy Preference Relation Based on Multiplicative Consistency. IEEE Trans. Fuzzy Syst. 2014, 22, 1669-1681. [CrossRef]

16. Bashir, Z.; Rashid, T.; Watróbski, J.; Sałabun, W.; Malik, A. Hesitant Probabilistic Multiplicative Preference Relations in Group Decision Making. Appl. Sci. 2018, 8, 398. [CrossRef]

17. Zhou, L.; Merigó, J.M.; Chen, H.; Liu, J. The optimal group continuous logarithm compatibility measure for interval multiplicative preference relations based on the COWGA operator. Inf. Sci. Int. J. 2016, 328, 250-269. [CrossRef]

18. Tang, J.; Meng, F. A Consistency-Based Method to Decision Making with Triangular Fuzzy Multiplicative Preference Relations. Int. J. Fuzzy Syst. 2017, 19, 1317-1332. [CrossRef]

19. Zhang, Z. Deriving the priority weights from incomplete hesitant fuzzy preference relations based on multiplicative consistency. Appl. Soft Comput. 2016, 46, 37-59. [CrossRef]

20. Jain, R. Decision-making in the presence of fuzzy variables. IEEE Trans. Syst. Man Cybern. 1976, 6, 698-703.

21. Yao, J.S.; $\mathrm{Wu}, \mathrm{K}$. Ranking fuzzy numbers based on decomposition principle and signed distance. Fuzzy Sets Syst. 2000, 116, 275-288. [CrossRef]

22. Gu, Q.; Xuan, Z. A new approach for ranking fuzzy numbers based on possibility theory. J. Comput. Appl. Math. 2016, 309, 674-682. [CrossRef]

(C) 2018 by the authors. Licensee MDPI, Basel, Switzerland. This article is an open access article distributed under the terms and conditions of the Creative Commons Attribution (CC BY) license (http://creativecommons.org/licenses/by/4.0/). 